\title{
Quantitative RT-PCR Detection of Hepatitis A Virus, Rotaviruses and Enteroviruses in the Buffalo River and Source Water Dams in the Eastern Cape Province of South Africa
}

\section{Vincent Nnamdigadi Chigor and Anthony Ifeanyi Okoh*}

Applied and Environmental Microbiology Research Group (AEMREG), Department of Biochemistry and Microbiology, University of Fort Hare, Private Bag X1314, Alice 5700, Eastern Cape, South Africa; E-Mail: vnchigor@yahoo.com

* Author to whom correspondence should be addressed; E-Mail: aokoh@ufh.ac.za; Tel.: +27-822-249-760.

Received: 24 September 2012; in revised form: 11 October 2012 / Accepted: 12 October 2012 / Published: 5 November 2012

\begin{abstract}
Human enteric viruses (HEntVs) are a major cause of water-related diseases. The prevalence of hepatitis A virus (HAV), rotaviruses (RoV) and enteroviruses (EnV) in Buffalo River waters was assessed quantitatively over a period of 12 months (August 2010 to July 2011). Seventy-two samples were collected from six sites, including three dams, and concentrated using the adsorption-elution method. Viral RNA was extracted using a commercial kit, and the viruses were quantified by real-time quantitative reverse transcriptase PCR (RT-qPCR). Two or more viruses were detected in $12.5 \%$ of the samples. HAV was detected in $43.1 \%$ of the samples and in significantly $(p<0.05)$ varying concentrations of $1.5 \times 10^{1}-1.9 \times 10^{5}$ genome copies/L compared to RoV and $\mathrm{EnV}$, while RoVs were detected in $13.9 \%$ of samples, with concentrations ranging from $2.5 \times 10^{1}-2.1 \times 10^{3}$ genome copies/L, and EnV were detected in $9.7 \%$ of the samples, with concentrations ranging from $1.3 \times 10^{1}-8.6 \times 10^{1}$ genome copies/L. Only HAV was detected at all the sites, with the Bridle Drift Dam recording significantly higher $(p<0.05)$ concentrations. The presence of enteric viruses in Buffalo River may constitute public health risks and the incidence of HAV at all the sites could reflect both the epidemiological status of hepatitis A and HAV persistence in the water environments.
\end{abstract}

Keywords: real-time RT-PCR; enteric RNA viruses; surface waters; detection; quantification; hepatitis A virus; rotaviruses; enteroviruses 


\section{Introduction}

Microbial contamination of water remains a problem of global concern [1,2] and lack of safe water and poor sanitation are important risk factors for mortality and morbidity, including diarrhoeal diseases, especially in the developing world $[1,3,4]$. A recent report by the WHO/UNICEF Joint Monitoring Programme for Water Supply and Sanitation shows that 884 million people, almost all of them in the developing regions of the World, still do not get their drinking-water from improved sources. Sub-Saharan Africa accounts for over a third of that number. The report further reveals that seven out of ten people without improved sanitation live in rural areas, and that worldwide, 37\% of people not using improved source of drinking water live in Sub-Saharan Africa [5]. South Africa is a semi-arid, water-stressed country sourcing water largely from rivers and dams for the production of drinking water, as well as for agricultural and recreational purposes [6]. However, such surface waters are vulnerable to faecal contamination [7-9].

Human enteric viruses (HEntVs) are excreted in high concentrations $\left(10^{5}\right.$ to $10^{13} / \mathrm{g}$ faeces) in the faeces of infected persons and have great potential to pollute water sources [10,11]. It has been estimated that $30-90 \%$ of waterborne disease outbreaks worldwide are caused by HEntVs [12]. HEntVs are transmitted mainly by the faecal-oral route, either direct from person-to-person or via consumption of contaminated food or water [13]. Over 140 enteric viruses are known to infect humans and they are considered to be emerging waterborne pathogens because of their high stability in the environment and resistance to current water treatment processes [12,14]. HEntVs belong to the families Picornaviridae (polioviruses, enteroviruses, coxsackieviruses, echoviruses and hepatitis A virus), Caliciviridae (noroviruses and sapoviruses), Astroviridae (astroviruses), Reoviridae (rotaviruses), Hepeviridae (hepatitis E virus) and Adenoviridae (adenoviruses) [15].

Aside from the adenoviruses that have a DNA genome, most health-significant waterborne viruses have RNA genomes. These enteric RNA viruses have low infective doses [16] and among the diseases caused by them are epidemic gastroenteritis, hepatitis, paralysis, meningitis and myocarditis $[11,17,18]$. Worldwide, while rotavirus and hepatitis A virus are the leading causes of epidemic gastroenteritis and acute hepatitis, respectively, enteroviruses are major causes of paralysis, meningitis and myocarditis [11,19-21].

Hepatitis A virus (HAV), a 27- to 32-nm non-enveloped, small, single-stranded RNA virus and the only member of the Hepatovirus genus [19] is the aetiological agent of hepatitis A which is hyperendemic in South Africa [22,23]. Rotavirus (RoV) is a non-enveloped, double-stranded RNA virus and the leading cause of severe diarrhoea among infants and young children, with an estimated 611,000 deaths from rotavirus infection per year worldwide [24], and almost half of all deaths worldwide are estimated to occur in Africa [25,26]. Enteroviruses (EnV) are non-enveloped, single-stranded RNA viruses that include poliovirus, coxsackieviruses, echoviruses and the numbered enteroviruses [20].

Waterborne outbreak of infections caused by these enteric RNA viruses have been reported worldwide [12,27-30], South Africa inclusive [31-33]. These viruses have also been detected in water sources globally [34-41]. A number of South Africa studies have also reported the detection or isolation enteric RNA viruses from water sources, including polio virus and non-polio enteroviruses [42-44], astroviruses [22,45], rotaviruses [46,47], and hepatitis A virus [22,23]. 
However, the studies that have assessed for viral agents in South Africa's waters have occurred only in a limited number of locations and provinces, and no records exist of similar investigations in Eastern Cape Province.

Recent studies have highlighted both the drawbacks of using only bacteriological indicators and the necessity of surveillance of source waters for viral pathogens towards protection of public health [48-50]. Standard methods for the detection of infectious viruses in water require the use of susceptible cell lines within which the viruses can propagate and produce cytopathic effects [35,51]. However, cell culture can be time-consuming, labour-intensive and unsuitable for the detection of some nonculturable/noncytopathic enteric viruses, for which either the appropriate cell cultures are not available (e.g., Norovirus) or the growth of the viruses is limited (e.g., HAV) [52,53]. Additionally, typically there is a low density of virus in water samples [19]. However, progress has been made developing molecular techniques and polymerase chain reaction (PCR) is currently the most widely used technique for the detection of viruses in various kinds water samples due to its high sensitivity and specificity $[11,12,35,54,55]$.

Reverse transcriptase PCR (RT-PCR) involves a step in which the viral RNA genome is reverse transcribed to a complementary DNA strand (cDNA) prior to the PCR and has been successfully used to monitor water for enteric RNA viral contamination [17,19,22,52]. Over conventional (qualitative) RT-PCR, real-time RT-PCR has the advantage of enabling sensitive and rapid the determination of concentrations of viral pathogens in environmental samples [56-60]. A major limitation of the PCR assays is their inability to determine the viability and infectivity of viruses detected, as the presence of viral nucleic acid does not necessarily indicate the presence of infectious viruses $[61,62]$. However, a recent study has demonstrated a statistical correlation between genome copy numbers and infectious enteric viral particles in wastewater samples and proposed that a cut off value of 200 genome copies could be used to indicate viral survival in environmental monitoring [63]. The use of propidium monoazide in RT-PCR (PMA-RT-PCR) has also been shown to be effective for distinguishing between infectious and noninfectious enteric RNA viruses in water samples [64]. We report the findings of our studies on the quantitative RT-PCR detection of hepatitis A virus, rotaviruses and enteroviruses in the Buffalo River, a major water resource in the Eastern Cape.

\section{Experimental Section}

\subsection{Study Area and Samples Collection}

Rising at an altitude of 1,200 $\mathrm{m}$ in the Amathola Mountains of the Eastern Cape, the Buffalo River (Figure 1) flows south-eastwards for about 126 kilometres before emptying into the Indian Ocean at East London harbour. The catchment supports about 570,000 people within its 1,287 $\mathrm{km}^{2}$ area [65]. Along the Buffalo River there are four dams supplying water to the urban areas of King William's Town, Zwelitsha, Mdantsane and East London. Buffalo River is not only important as the major source for raw water abstraction; it is used also for irrigation and recreational purposes. 
Figure 1. The study area and sampling sites.
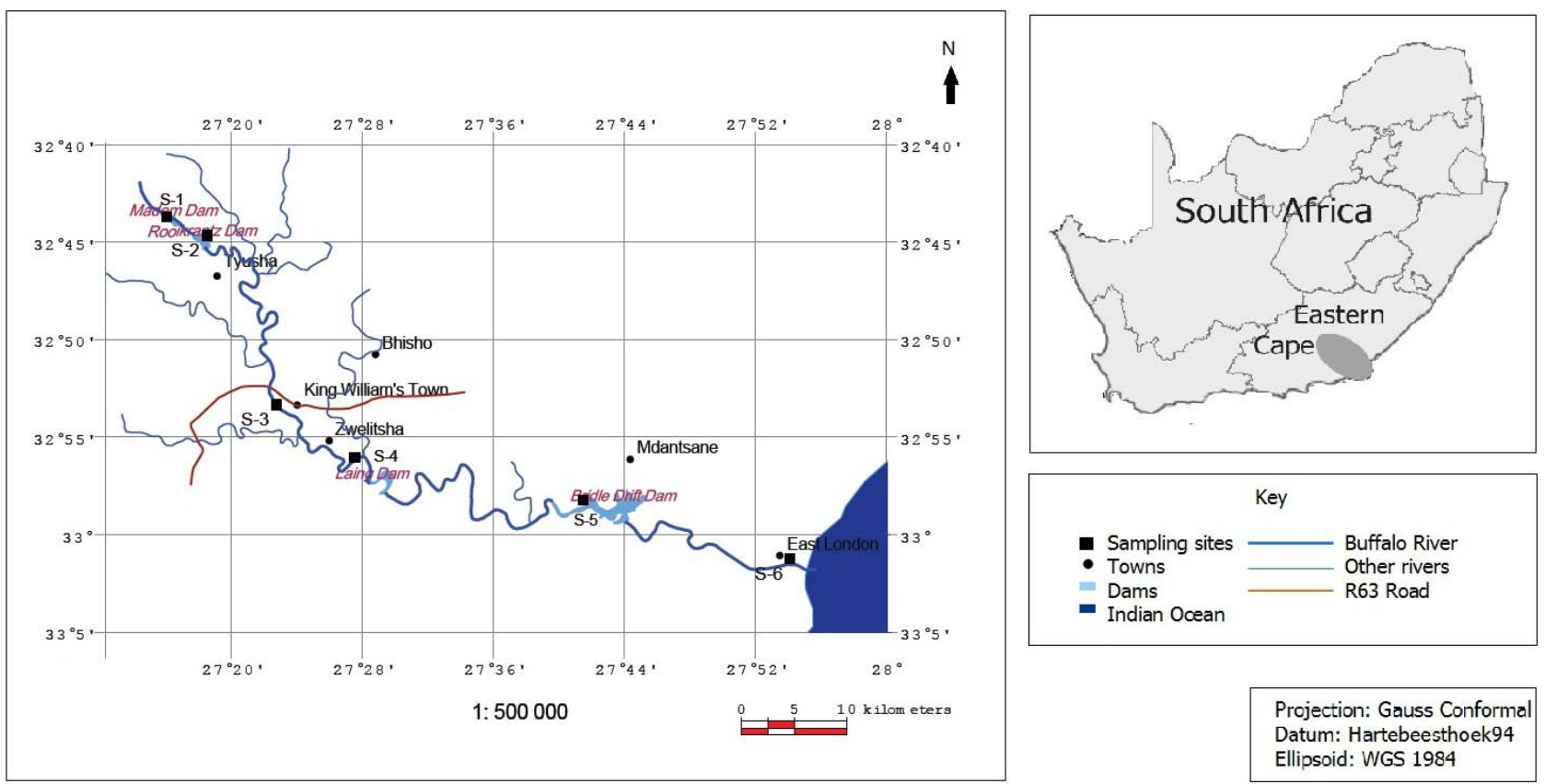

Six different sampling sites were identified on the river course using a GPS instrument (Garmin; eTrex Legend H). These include S-1, Maden Dam (3244'22"S; $\left.7^{\circ} 17^{\prime} 54^{\prime \prime E}\right)$, S-2, Rooikrantz Dam

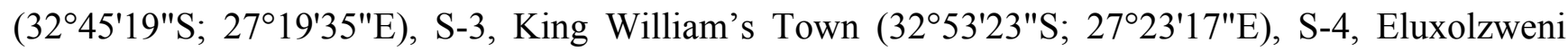

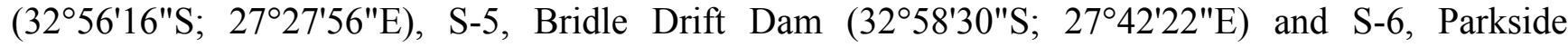
(3301'23"S; 2751'31"E), in East London. From August 2010 to July 2011, water samples were collected monthly from the sites using sterile 1.75-litre screw-capped bottles and transported on ice to the Applied and Environmental Microbiology Research Group (AEMREG) laboratory at the University of Fort Hare, Alice, South Africa where they were kept at $4{ }^{\circ} \mathrm{C}$ until processing as recommended by American Public Health Association [66].

\subsection{Concentration of Viruses in Water}

The water samples were first passed through glass fibre prefilters (Millipore, County Cork, Ireland) to remove debris and minimize membrane clogging. Concentration was carried out following the adsorption-elution method of Haramoto et al. [67]. This method based on electrostatic interactions was reported to have shown a recovery efficiency of $56 \% \pm 32 \%(n=37)$ for surface water samples inoculated with polioviruses. Briefly, $5 \mathrm{~mL}$ of $250 \mathrm{mM} \mathrm{AlCl}_{3}$ was passed through an HA filter $(0.45 \mu \mathrm{m}$ pore size and $47 \mathrm{~mm}$ diameter; Millipore) to form a cation $\left(\mathrm{Al}^{3+}\right)$-coated filter, and then one litre of the river water sample was filtered through. The filter was then rinsed with $200 \mathrm{~mL}$ of $0.5 \mathrm{mM} \mathrm{H}_{2} \mathrm{SO}_{4}$ (pH 3.0), followed by elution of viruses with $10 \mathrm{~mL}$ of $1.0 \mathrm{mM} \mathrm{NaOH}$ (pH 10.8). This acid rinse removes the $\mathrm{Al}^{3+}$ and allows the viruses to attach directly to the negatively charged membrane. The eluate was recovered in a tube containing $50 \mu \mathrm{L}$ of $100 \mathrm{mM} \mathrm{H}_{2} \mathrm{SO}_{4}(\mathrm{pH} 1.0)$ and $100 \mu \mathrm{L}$ of $100 \times$ Tris-EDTA (TE) buffer $(\mathrm{pH} 8.0)$ for neutralization, followed by centrifugation using a Centriprep ${ }^{\circledR}$ centrifugal filter, Ultracel ${ }^{\circledR}$ YM-50 (Millipore), according to the manufacturer's protocol. Ultracentrifugation, using a centrifuge (Model TJ-6; Beckman, Brea, CA, USA), was carried out at 
$2,500 \mathrm{rpm}$ for $10 \mathrm{~min}$. This was followed by removal of the sample that passed through the ultrafiltration membrane (about $8 \mathrm{~mL}$ ) and further centrifugation at 2,500 rpm for 5 min to obtain a final volume of about $700 \mu \mathrm{L}$. Each final concentrated sample was aliquoted in $200 \mu \mathrm{L}$ regimens and stored at $-80{ }^{\circ} \mathrm{C}$ until further analysis [67].

\subsection{Quantification of Viruses}

The concentration of the viruses in the samples was determined by real-time RT-PCR using a StepOnePlus PCR System (OPTIPLEX 755, Applied Biosystems, Foster City, CA, USA) and following a two-step protocol involving a reverse-transcription step and complementary DNA (cDNA)-based qPCR step. The real-time procedures for HAV were based on the amplification of a fragment of the highly conserved 5' noncoding region (5' NCR) [56]. The rotavirus real-time RT-PCR assay utilized primers and probe that were designed to target the non-structural protein region 3 (NSP3) of rotavirus [59]. The pan-enteroviral primers and probe are specific for a 143-nucleotide portion of the $5^{\prime}$ untranslated region (5' UTR) of poliovirus. This $5^{\prime}$ UTR region is highly conserved in non-polio enteroviruses and poliovirus types [57]. All the primers and probes used in this study (Table 1) were designed by previous investigators and synthesized by Applied Biosystems.

Table 1. Primers, probes, and control viruses used for the real-time RT-PCR.

\begin{tabular}{|c|c|c|c|}
\hline Enteric virus & Primers and labelled TaqMan probe & Reference & Control virus \\
\hline $\begin{array}{l}\text { Hepatitis A } \\
\text { virus }\end{array}$ & $\begin{array}{c}\text { HAV68 (F): 5'-TCA CCG CCG TTT GCC TAG-3' } \\
\text { HAV240 (R): 5'-GGA GAG CCC TGG AAG AAA G-3' } \\
\text { HAV150 (P): 5'-FAM-CCT GAA CCT GCA GGA ATT } \\
\text { AA-MGBNFQ-3' }\end{array}$ & [56] & $\begin{array}{c}\text { ATCC VR-1357; } \\
\text { Strain PA21 }\end{array}$ \\
\hline Rotaviruses & $\begin{array}{l}\text { JVK (F): 5'-CAGTGGTTGATGCTCAAGATGGA-3' } \\
\text { JVK (R): 5'-TCATTGTAATCATATTGAATACCCA-3' } \\
\text { JVK (P): 5'-FAM- } \\
\text { ACAACTGCAGCTTCAAAAGAAGWGT-MGBNFQ-3' }\end{array}$ & [59] & $\begin{array}{l}\text { ATCC VR-2274; } \\
\quad \text { Strain } 248\end{array}$ \\
\hline Enteroviruses & $\begin{array}{c}\text { EV1 (F): 5'-CCCTGAATGCGGCTAAT-3' } \\
\text { EV1 (R): 5'-TGTCACCATA AGCAGCCA-3' } \\
\text { EV-BHQ (P): 5'-FAM- } \\
\text { ACGGACACCCAAAGTAGTCGGTTC-MGBNFQ-3' }\end{array}$ & [57] & $\begin{array}{l}\text { Coxsackie virus A2 } \\
\text { (ATCC VR-1550; } \\
\text { Strain } \\
\text { FLEETWOOD) }\end{array}$ \\
\hline
\end{tabular}

Abbreviations: F, forward/sense; R, reverse/antisense; P, probe; FAM, 6-carboxyfluorescein (reporter dye); MGBNFQ, minor groove binder/nonfluorescent quencher.

\subsubsection{RNA Extraction}

Viral RNA was extracted from $200 \mu \mathrm{L}$ of the sample (eluate) using a commercial RNA purification kit, Quick-RNA ${ }^{T M}$ MiniPrep (Zymo Research, Irvine, CA, USA). The manufacturer's protocol was followed, and the purified viral RNA was eluted in $60 \mu \mathrm{L}$ of RNase-free water.

\subsubsection{Reverse-Transcription}

In the reverse-transcription step, to $10 \mu \mathrm{L}$ out of the $60 \mu \mathrm{L}$ of the extracted RNA were added $1 \mu \mathrm{L}$ of $100 \mu \mathrm{M}$ Random Hexamer primer, $1 \mu \mathrm{L}$ dNTP mix $(10 \mathrm{mM}$ each of the four deoxynucleoside 
triphosphate stocks), $2.5 \mu \mathrm{L}$ DEPC-treated water, $4 \mu \mathrm{L} 5 \times$ RT buffer, $0.5 \mu \mathrm{L}$ Ribolock RNase inhibitor and $1 \mu \mathrm{L}$ of $200-\mathrm{U} / \mu 1$ RevertAid ${ }^{\mathrm{TM}}$ Premium reverse transcriptase (Fermentas, Burlington, $\mathrm{ON}$, Canada) in the indicated order into a $0.5 \mathrm{~mL}$ PCR tube on ice. The reaction mixture $(25 \mu \mathrm{L})$ was briefly vortexed to ensure total mixing and then centrifuged. The tubes were then incubated at $25{ }^{\circ} \mathrm{C}$ for $10 \mathrm{~min}$ followed by $30 \mathrm{~min}$ at $60{ }^{\circ} \mathrm{C}$. The reaction was terminated by heating at $85{ }^{\circ} \mathrm{C}$ for $5 \mathrm{~min}$. The resulting $20 \mu \mathrm{L}$ of cDNA was kept at $-20^{\circ} \mathrm{C}$ until use for qPCR. For RoV, prior to reverse-transcription, the RNA was subjected to denaturation at $95{ }^{\circ} \mathrm{C}$ for $5 \mathrm{~min}$ followed by flash chilling in ice for $2 \mathrm{~min}$, to separate the double-stranded rotaviral RNA [59].

\subsubsection{Quantitative PCR (qPCR)}

Briefly, $5 \mu \mathrm{L}$ out of $20 \mu \mathrm{L}$ of the cDNA was mixed with $20 \mu \mathrm{L}$ of a reaction buffer (containing $12.5 \mu \mathrm{L}$ of $2 \times$ TaqMan universal PCR master mix (Applied Biosystems), $400 \mathrm{nM}$ sense primer, $400 \mathrm{nM}$ antisense primer, and $250 \mathrm{nM}$ TaqMan probe and PCR grade water to give a $25-\mu \mathrm{L}$ total reaction mixture [13]. Subsequently, the mixture was added to a well of a 96-well micro-plate and loaded into the StepOnePlus PCR System. Fluorescence data were collected at the end of annealing step. The thermal cycling protocols used for the respective viruses are shown in Table 2.

Table 2. The thermal cycling protocols for qPCR, using cDNA of the respective RNA viruses.

\begin{tabular}{ccccc}
\hline \multirow{2}{*}{ Virus } & \multirow{2}{*}{ Taq activation } & \multicolumn{3}{c}{$\mathbf{4 5}$ cycles of: } \\
\cline { 3 - 5 } & & Denaturation & Annealing & Extension \\
\hline Hepatitis A virus & $10 \min$ at $95{ }^{\circ} \mathrm{C}$ & $15 \mathrm{~s}$ at $95{ }^{\circ} \mathrm{C}$ & 1 min at $60{ }^{\circ} \mathrm{C}$ & 1 min at $70{ }^{\circ} \mathrm{C}$ \\
Rotaviruses & 15 min at $95{ }^{\circ} \mathrm{C}$ & $15 \mathrm{~s}$ at $95^{\circ} \mathrm{C}$ & $30 \mathrm{~s}$ at $55^{\circ} \mathrm{C}$ & $30 \mathrm{~s}$ at $72{ }^{\circ} \mathrm{C}$ \\
Enteroviruses & $10 \min$ at $95^{\circ} \mathrm{C}$ & $15 \mathrm{~s}$ at $94^{\circ} \mathrm{C}$ & 1 min at $58{ }^{\circ} \mathrm{C}$ & $20 \mathrm{~s}$ at $72{ }^{\circ} \mathrm{C}$ \\
\hline
\end{tabular}

\subsubsection{The Standard Curve}

The standard curve was obtained as described by Haramoto et al. [58]. Briefly, the viral RNA was extracted from each positive control strain using Quick-RNA ${ }^{T M}$ MiniPrep (Zymo Research). RNA extracts was then reverse-transcribed into cDNA. The cDNA was then quantified (in $\mu \mathrm{g} / \mathrm{mL}$ ) using a Qubit fluorometer (Invitrogen, Carlsbad, CA, USA) and diluted to $10 \mu \mathrm{g} / \mathrm{mL}$, equivalent to $10 \mathrm{ng} / \mu \mathrm{L}$. This quantity was then diluted by serial ten-fold dilution. Viral cDNA generated from the samples and standards were each run in duplicate and simultaneously. The runs were followed by analysis using SDS software (Applied Biosystems) to obtain quantitative data used to calculate the target gene concentration. A sample with threshold cycle $\left(\mathrm{C}_{\mathrm{T}}\right)$ value of $\leq 35$ was defined as positive. The concentrations of the viruses in the river water samples from the studied sites are equivalent to the target gene copies per liter (i.e., each HAV, RoV and EnV particle consists of one copy of the 5' NCR, NSP3 and 5' UTR gene, respectively).

\subsection{Quality Control}

Negative controls (non-spiked autoclaved distilled water) and positive controls (virus suspensions) were incorporated with each set of test samples and subjected to RNA extraction and PCR assays. To avoid the number of false-positives resulting from carryover contamination of the samples or 
amplified cDNA, virus control extractions were carried out using a safety cabinet. RNA extractions from water samples, reverse transcription of the extracted RNA into cDNA and PCR amplifications were performed in separate laboratory rooms. Viral reference strains (Table 1) were obtained from the American Type Culture Collection (ATCC, Manasas, VA, USA). All qPCR runs included a negative control reaction (PCR-grade $\mathrm{H}_{2} \mathrm{O}$ without template). To prove the specificity of the primer sets for the detection of human enteroviral viral particles, bovine enterovirus Type 1 (ATCC VR-248) was included as a negative control in the qPCR assay for enteroviruses. No internal amplification control (IAC) was included in these assays. The detection limit for each virus was determined to be 10 genome copies/litre. For accurate and precise measurements, a broad range of standard quantities ( 7 logs) were used to construct the standard curves for HAV ( $\left.\mathrm{Y}=-3.479 \mathrm{x}+39.861 ; \mathrm{R}^{2}=0.970\right)$, RoV $\left(\mathrm{Y}=-3.359 \mathrm{x}+18.483 ; \mathrm{R}^{2}=0.999\right)$ and $\operatorname{EnV}\left(\mathrm{Y}=-3.809 \mathrm{x}+33.261 ; \mathrm{R}^{2}=0.998\right)$. DNAZap ${ }^{\mathrm{TM}}$ solution $\left(\right.$ Ambion $^{\circledR}$, Foster City, CA, USA), which completely degrades all RNA and DNA, was used to always wash the pipettes to prevent carryover contaminations.

\subsection{Statistical Analysis}

One-way ANOVA and Tukey's test were carried out to test differences among the mean concentrations, using the Statistical Package for the Social Sciences (IBM SPSS Statistics release 19; IBM, Armonk, NY, USA).

\section{Results and Discussion}

Figure 2 shows the results for quantitative detection of HAV, RoV and EnV and reveals spatial and monthly variations in concentrations of these viruses $\left(\log _{10}\right.$ genome copies/L) in water samples collected from six sites on the Buffalo River. Figure 3 shows the detection rate per site. Detection rates and viral concentrations varied with sites and virus, with significantly higher $(p<0.05)$ concentrations and very high detection rates being recorded for Bridle Drift Dam and HAV. While only HAV was detected at all the sites, it was only at King William's Town, Eluxolzweni and Parkside that all three enteric RNA viruses studied were detected.

Figure 2. Spatial and monthly variations in concentrations of enteric RNA viruses $\left(\log _{10}\right.$ genome copies/litre) in water samples collected from six sites in the Buffalo River.

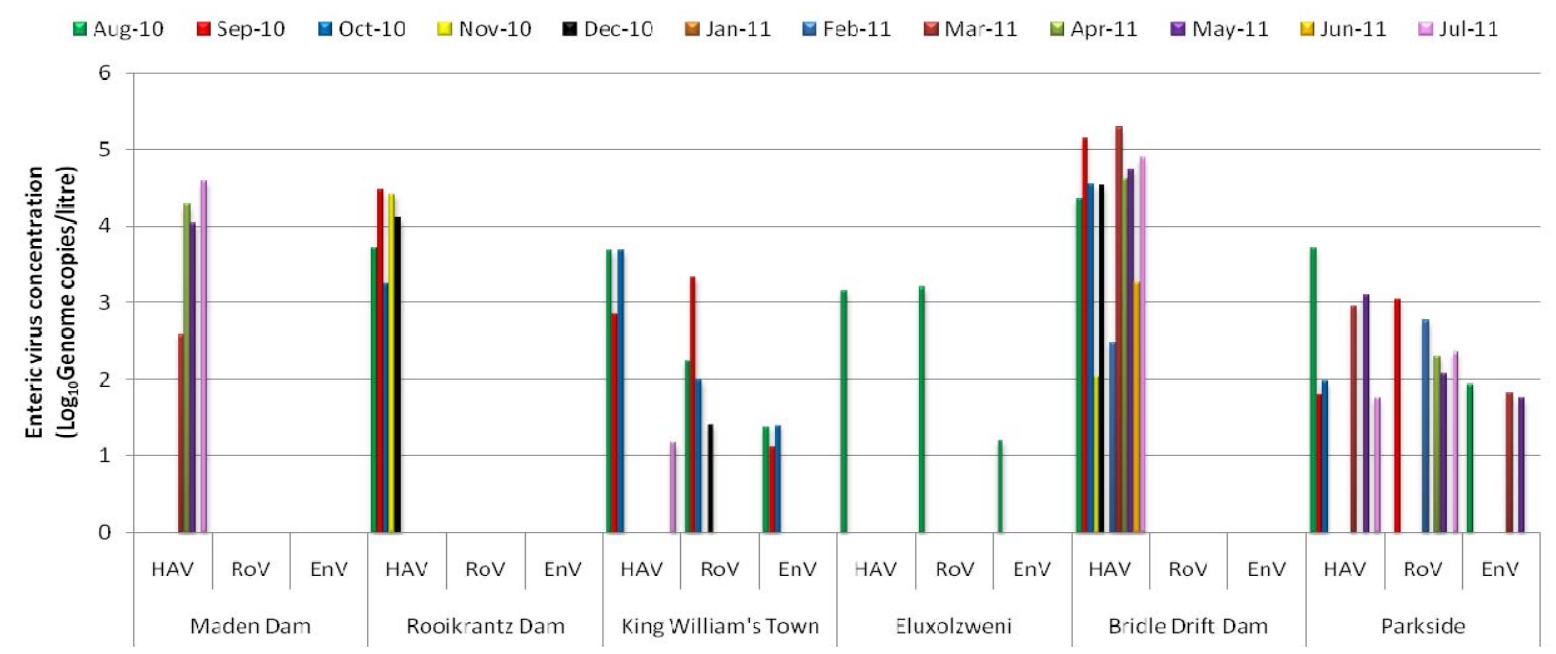


Figure 3. The detection rates for enteric viruses in the Buffalo River and at the six sampling sites along the Buffalo River.

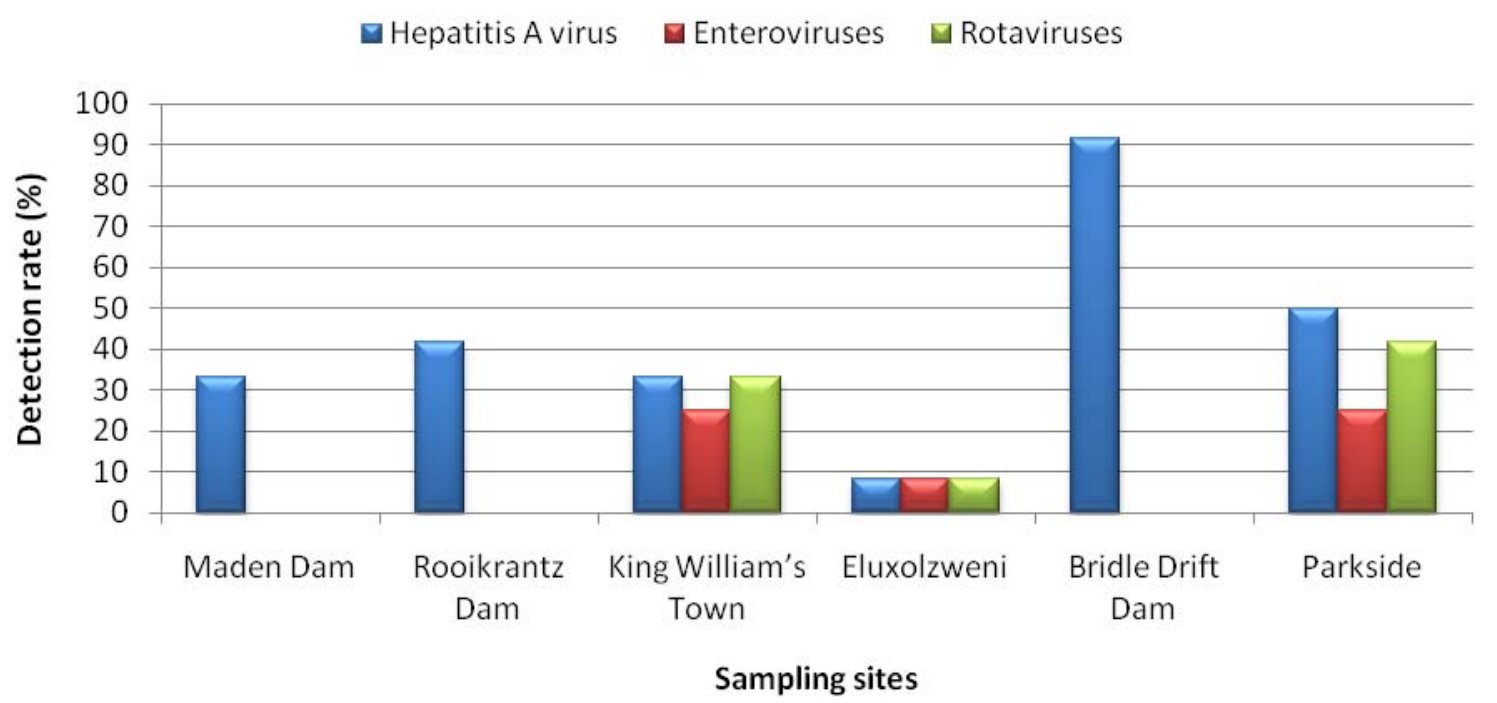

HAV was detected at all the sites and in all but one (January) of the 12 months in $43 \%$ (31/72) of the samples, with concentrations ranging from $1.5 \times 10^{1}-1.9 \times 10^{5}$ genome copies/L. This high detection rate is similar to a previous report from South Africa [22], in which HAV was detected in $35.3 \%$ of the river and $37.3 \%$ of the dam water samples tested. However, it is higher than that of a 2007 report in which Venter et al. [23] reported the detection of HAV in 17.5\% of river and 14.9\% of dam water samples they tested. The presence of HAV at all the sites may suggest that the virus is consistently present in Buffalo River. The Bridle Drift Dam samples yielded a detection rate (91.7\%) with HAV concentrations ranging from $1.1 \times 10^{2}-1.9 \times 10^{5}$ genome copies/L. HAV was detected in $50 \%(6 / 12)$ of samples collected at Parkside, with concentrations ranging from $5.6 \times 10^{1}-5.2 \times 10^{3}$ genome copies/L, in 41.7\% (5/12) at Rooikrantz Dam, with concentrations raging from $1.7 \times 10^{3}-2.9 \times 10^{4}$ genome copies/L, in 33.3\% (4/12) at Maden Dam, with concentrations ranging from $3.8 \times 10^{2}-3.9 \times 10^{4}$ genome copies/L), in $33.3 \%(4 / 12)$ at King William's Town, with concentrations ranging from $1.5 \times 10^{1}-4.8 \times 10^{3}$ genome copies/L and in $8.3 \%(1 / 12)$ at Eluxolzweni, with a concentration of $1.4 \times 10^{3}$ genome copies/L.

The highest detection rate of $91.7 \%$ for HAV observed at Bridle Drift Dam, with a mean concentration of $5.4 \times 10^{4}$ genome copies/ $\mathrm{L}$, is not surprising. The dam is located in and downstream of densely populated areas and discharge points of sewage treatment works that are not very efficient $[65,68]$. HEntVs are excreted in high concentrations $\left(10^{5}\right.$ to $10^{13} / \mathrm{g}$ faeces) in the faeces of infected persons, have great potential to pollute water sources [10], and the discharge of inadequately treated sewage effluents is the most common source of enteric viral pathogens in aquatic environments [8]. The high detection rates (33-42\%) and mean concentrations that were observed for HAV at Maden Dam $\left(1.72 \times 10^{4}\right.$ genome copies/L) and Rooikrantz Dam $\left(1.49 \times 10^{4}\right.$ genome copies/L) are unexpected, considering the very low human population densities of the catchments of the two dams. However, HAV has been shown to cause acute hepatitis, not only in humans but also in some primates $[36,69,70]$, and the bushy and mountainous catchments of the two dams were observed to host a high population of monkeys. The sequence alignment of target regions of the primers and probe used in this study proved them to be adequate for the quantification of all HAV genotypes [56]. Although the natural 
transmission of human HAV from experimentally infected animals to humans is well documented, the susceptibility of humans to true simian HAV strains is still unknown [71]. Should the HAV detected in this study (especially at both Maden and Rooikrantz dams) be simian genotypes, the waters from both dams therefore could represent no HAV-related risks for public health. There is need for genotypic characterization of the detected HAV which could differentiate between possible simian strains from the human strains.

HAV was detected more often in the winter and spring months. In general terms, the detection of hepatitis A virus in Buffalo River is similar to other studies in other provinces in South Africa [22,23] and elsewhere [54]. While the detection rate for HAV in this study was about $43 \%(31 / 72)$, in the study by Taylor et al. [22], HAV was detected in 18 (35.3\%) of river and 19 (37.3\%) of dam water samples, with a seasonal peak being evident in both the river and dam water in early spring (August and September). It was also during these two months that HAV was detected most often in this study. Although Taylor and colleagues detected HAV less often in the months of May, June and July, it was during the months of January and February that the least HAV detection was recorded in this study. Considering that we used real-time quantitative reverse transcriptase-polymerase chain reaction (RT-qPCR) which is more sensitive, compared with the combination of cell culture amplification and qualitative RT-PCR used by Taylor, the variations were not unexpected.

The RoV concentrations ranged from $2.5 \times 10^{1}$ genome copies/L to $2.1 \times 10^{3}$ genome copies/L and RoV were detected in 14\% (10/72) of the samples (Figure 2). In a report by van Zyl et al. [47], on the molecular epidemiology of Group A rotaviruses in water sources and selected raw vegetables in Southern Africa, Group A RoV were detected in $11.8 \%$ of partially treated and $1.7 \%$ of finally treated drinking water samples; in 14\% of irrigation water samples; and $1.7 \%$ of corresponding raw vegetable samples. However, higher detection rates have been reported elsewhere. Lodder et al. [72] reported the detection of RoV in $48 \%$ of the surface water samples in The Netherlands. The frequency of virus detection varied greatly between the locations. Fifty percent of RoV detections occurred at Parkside, $40 \%$ at King William's Town, and $10 \%$ at Eluxolzweni. No RoV was evident at any of the three dams. This could be due to human population difference along the river course. The lower catchments are significantly more populated than the upper catchments. In a similar report from Kenya, Kiulia et al. [41] detected Group A rotavirus in $10(100 \%)$ of samples collected from a river located in urban area and in three $(25 \%)$ of rural river water samples.

Several studies on the seasonality of rotavirus at various locations with different climatic conditions in South Africa identified two recurrent features of the disease. First, rotavirus infection occurred year-round in all locations studied; and secondly, in each region, rotavirus cases increased during the cooler and drier months [73]. In this study, RoVs were detected in each of the four seasons. Also, $80 \%$ of all RoV detections were made in the cooler months of August to October in 2010 and April to July in 2011. Only $20 \%$ of RoV detections occurred in summer months of December and February.

In this study, the detection rate for $\mathrm{EnV}$ was $9.7 \%$ (7/72), with concentrations that ranged from $1.3 \times 10^{1}$ genome copies/L to $8.6 \times 10^{1}$ genome copies/L. In a study that had been previously conducted in South Africa, Ehlers et al. [74], who used a combination of cell culture and nested-PCR, reported the presence of enteroviruses in $42.5 \%$ of sewage, $18.7 \%$ of treated drinking water, $28.5 \%$ of river water, $26.7 \%$ of dam/spring water and in $25.3 \%$ of borehole water samples. The detection rate of 
9.7\% observed for EnV in this study is unexpectedly low considering the high sensitivity of the RT-qPCR used in this study and reported high seroprevalence for enteroviruses in human populations [75].

While no EnV were detected during the hotter months (November 2010 to February 2011), 42.8\% of all EnV detections were made in the winter month of August (Figure 2). This is consistent with previous studies that reported a significant correlation between low water temperatures and occurrence of enteroviruses in water [76]. EnV were detected in 9.7\% (7/72) of the samples by real-time RT-PCR and in $1.4 \%(1 / 72)$ by semi-nested reverse transcriptase PCR, thus reaffirming the higher sensitivity of qRT-PCR in comparison with conventional RT-PCR [54]. The detection rate of $1.4 \%$, by semi-nested PCR, recorded in this study is similar to the $1.2 \%$ reported elsewhere [52].

While about 57\% (4/7) of the positive samples were from a combination of two freshwater sites (three samples from King William's Town and one from Eluxolzweni), about 43\% (3/7) of the EnV-positive samples were from the Buffalo estuary. This observation is consistent with reports that EnV are tolerant of a wide range of temperatures and salinities which facilitates their survival in environmental waters [57,77]. However, our findings apparently differ from the results presented by Schvoerer et al. [52], in which they studied 26 water samples in southwestern France, and detected EnV in freshwater, but not in seawater. A comparison of the detection rates of the three enteric RNA viruses assessed in this study (Figure 3) reveals that only HAV was detected at all the sites. Neither RoV nor EnV was detected at any of the dams. The mean concentration of HAV $\left(2.5 \times 10^{4}\right.$ genome copies/L) detected in the Buffalo River was significantly higher $(p \quad 0.05)$ than that $\operatorname{RoV}\left(6.2 \times 10^{2}\right.$ genome copies/L) and EnV $\left(4.0 \times 10^{1}\right.$ genome copies/L). This may reflect both the epidemiological status of infections caused by these viruses and there survival in the water environments.

\section{Conclusions}

Contamination of watercourses with enteric viruses represents a significant risk to public health. Although the RT-qPCR method used in this study does not directly test for viral infectivity, our results show that water samples from Buffalo River and the source water dams along its course were heavily contaminated with hepatitis A virus and to a lesser extent with rotaviruses and enteroviruses. The presence of HEntVs in water is therefore a potential health risk for the rural communities that use the water for domestic purposes and also the persons who swim in the river and dams or eat fresh-produce irrigated with water from these sources. The seriousness of the health effects from a viral infection will depend, however on the specific virus, as well as the characteristics of the individual affected (e.g., age, health status). The risk is heightened by the low infective doses of these viruses. Future research involving the genotypic characterization of the detected HAV could differentiate between possible simian strains from the human strains.

\section{Acknowledgments}

The authors are grateful to the Water Research Commission (WRC) of South Africa for funding this research and the Education Trust Fund of Nigeria for study bursary awarded to VNC. 


\section{Conflict of Interest}

The authors declare no conflict of interest.

\section{References}

1. World Health Organization (WHO). World Health Statistics 2009; WHO Press: Geneva, Switzerland, 2009; pp. 1-149.

2. Gibson, K.E.; Schwab, K.J. Detection of bacterial indicators and human and bovine enteric viruses in surface water and groundwater sources potentially impacted by animal and human wastes in Lower Yakima Valley, Washington. Appl. Environ. Microbiol. 2011, 77, 355-362.

3. Pruss, A.; Kay, D.; Fewtrell, L.; Bartram, J. Estimating the burden of disease from water sanitation and hygiene at a global level. Environ. Health Perspect. 2002, 110, 537-542.

4. Boschi-Pinto, C.; Velebit, L.; Shibuya, K. Estimating child mortality due to diarrhoea in developing countries. Bull. World Health Organ. 2008, 86, 710-717.

5. World Health Organization (WHO) and UNICEF. Progress on Sanitation and Drinking-Water: 2010 Update; WHO Press: Geneva, Switzerland, 2010; pp. 1-60.

6. Muller, M.; Schreiner, B.; Smith, L.; van Koppen, B.; Sally, H.; Aliber, M.; Cousins, B.; Tapela, B.; van der Merwe-Botha, M.; Karar, E.; Pietersen, K. Water Security in South Africa; Development Planning Division DBSA: Midrand, South Africa, 2009.

7. Shuval, H.I. Wastewater Irrigation in Developing Countries: Health Effects and Technical Solutions; The World Bank: Washinton, DC, USA, 1990; pp.1-19.

8. Okoh, A.I.; Sibanda, T.; Gusha, S.S. Inadequately treated wastewater as a source of human enteric viruses in the environment. Int. J. Environ. Res. Pub. Health 2010, 7, 2620-2637.

9. Chigor, V.N.; Umoh, V.J.; Okuofu, C.A.; Ameh, J.B.; Igbinosa, E.O.; Okoh, A.I. Water quality assessment: Surface water sources used for drinking and irrigation in Zaria, Nigeria are a public health hazard. Environ. Monit. Assess. 2012, 184, 3389-3400.

10. Miagostovich, M.P.; Ferreira, F.F.M.; Guimaraes, F.R.; Fumian, T.M.; Diniz-Mendes, L.; Luz, S.L.B.; Silva, L.A.; Leite, J.P.G. Molecular detection and characterization of gastroenteritis viruses occurring naturally in the stream waters of Manaus, central Amazonia, Brazil. Appl. Environ. Microbiol. 2008, 74, 375-382.

11. Bosch, A.; Guix, S.; Sano, D.; Pinto, R.M. New tools for the study and direct surveillance of viral pathogens in water. Curr. Op. Biotechnol. 2008, 19, 1-7.

12. Fong, T.T.; Lipp, E.K. Enteric viruses of human and animals in aquatic environments: Heath risks, detection and potential water quality assessment tools. Appl. Environ. Microbiol. 2005, 69, $357-371$.

13. Haramoto, E.; Katayama, H.; Utagawa, E.; Ohgaki, S. Development of sample storage methods for detecting enteric viruses in environmental water. J. Virol. Methods 2008, 151, 1-6.

14. Bosch, A. Human enteric viruses in the water environment: A minireview. Int. Microbiol. 1998, 1, 191-196. 
15. Fauquet, C.M.; Mayo, M.A.; Maniloff, J.; Desselberger, U.; Ball, L.A. Virus Taxonomy. Eighth Report of the International Committee on Taxonomy of Viruses; Elsevier Academic Press: San Diego, CA, USA, 2005; pp. 853-857.

16. Ward, R.L.; Bernstein, D.I.; Young, E.C.; Sherwood, J.R.; Knowlton, D.R.; Schiff, G.M. Human rotavirus studies in volunteers: Determination of infectious dose and serological response to infection. J. Infect. Dis. 1986, 154, 871-880.

17. Pusch, D.; Oh, D.Y.; Wolf, S.; Dumke, R.; Schroter-Bobsin, U.; Hohne, M.; Roske, I.; Schreier, E. Detection of enteric viruses and bacterial indicators in German environmental waters. Arch. Virol. 2005, 150, 929-947.

18. Liu, J.; Kibiki, G.; Maro, V.; Maro, A.; Kumburu, H.; Swai, N.; Taniuchi, M.; Gratz, J.; Toney, D.; Kang, G.; Houpt, E. Multiplex reverse transcription PCR Luminex assay for detection and quantitation of viral agents of gastroenteritis. J. Clin. Virol. 2011, 50, 308-313.

19. Kittigul, L.; Uthaisin, A.; Ekchaloemkiet, S.; Utrarachkij, F.; Luksamijarulkul, P. Detection and characterization of hepatitis A virus in water samples in Thailand. J. Appl. Microbiol. 2006, 100, 1318-1323.

20. Colbere-Garapin, F.; Martin-Latil, S.; Blondel, B.; Mousson, L.; Pelletier, I.; Autret, A.; Francois, A.; Niborski, V.; Grompone, G.; Catonnet, G.; van de Moer, A. Prevention and treatment of enteric viral infections: Possible benefits of probiotic bacteria. Microb. Infect. 2007, 9, 1623-1631.

21. Roque-Afonso, A.M.; Desbois, D.; Dussaix, E. Hepatitis A virus: Serology and molecular diagnostics. Future Virol. 2010, 5, 233-242.

22. Taylor, M.B.; Cox, N.; Very, M.A.; Grabow, W.O.K. The occurrence of hepatitis A and astroviruses in selected river and dam waters in South Africa. Water Res. 2001, 35, 2653-2660.

23. Venter, J.M.E.; van Heerden, J.; Vivier, J.C.; Grabow, W.O.K.; Taylor, M.B. Hepatitis A virus in surface water in South Africa: What are the risks? J. Water Health 2007, 5, 229-240.

24. MacIntyre, U.E.; de Villiers, F.P.R. The Economic burden of diarrheal disease in a tertiary level hospital, Gauteng, South Africa. J. Infect. Dis. 2010, 202, S116-S125.

25. Mwenda, J.M.; Ntoto, K.M.; Abebe, A.; Enweronu-Laryea, C.; Amina, I.; Mchomvu, J.; Kisakye, A.; Mpabalwani, E.M.; Pazvakavambwa, I.; Armah, G.E.; Seheri, L.M.; Kiulia, N.M.; Page, N.; Widdowson, M.A.; Steele, A.D. Burden and epidemiology of rotavirus diarrhea in selected African countries: preliminary results from the African Rotavirus Surveillance Network. J. Infect. Dis. 2010, 202, S5-S11.

26. Patel, M.M.; Steele, D.; Gentsch, J.R.; Wecker, J.; Glass, R.I.; Parashar, U.D. Real-world impact of rotavirus vaccination. Pediat. Infect. Dis. J. 2011, 30, S1-S5.

27. Ramachandran, M.; Gentsch, J.R.; Parashar, U.D.; Jin, S.; Woods, P.A.; Holmes, J.L.; Kirkwood, C.D.; Bishop, R.F.; Greenberg, H.B.; Urasawa, S.; Gerna, G.; Coulson, B.S.; Taniguchi, K.; Bresee, J.S.; Glass, R.I. Detection and characterization of novel rotavirus strains in the United States. J. Clin. Microbiol. 1998, 36, 3223-3229.

28. Adah, M.; Wade, A.; Taniguchi, K. Molecular epidemiology of rotaviruses in Nigeria: Detection of unusual strains with G2P [6] and G8P [1] specificities. J. Clin. Microbiol. 2001, 39, 3969-3975.

29. Pinto, R.M.; Saiz, J.C. Enteric Hepatitis Viruses. In Human Viruses in Water; Bosch, A., Ed.; Elsevier: Amsterdam, The Netherlands, 2007; pp. 39-67. 
30. Tallon, L.A.; Love, D.C.; Moore, Z.S.; Sobsey, M.D. Recovery and sequence analysis of hepatitis A virus from springwater implicated in an outbreak of acute viral hepatitis. Appl. Environ. Microbiol. 2008, 74, 6158-6160.

31. Taylor, M.B.; Schildhauer, C.I.; Parker, S.; Grabow, W.O.; Xi, J.; Estes, M.K. Two successive outbreaks of SRSV-associated gastroenteritis in South Africa. J. Med Virol. 1993, 41, 18-23.

32. Mans, J.; de Villiers, J.C.; du Plessis, N.M.; Avenant, T.; Taylor, M.B. Emerging norovirus GII.4 2008 variant detected in hospitalised paediatric patients in South Africa. J. Clin. Virol. 2010, 49, 258-264.

33. Rinaldi, M.; Brierley, E.; Bekker, A. Donor breastmilk saved infant lives during an outbreak of rotavirus in South Africa. Breastfeeding Medicine 2009, 4, 133-134.

34. Griffin, D.W.; Gibson, C.J.III; Lipp, E.K.; Riley, K.; Paul, J.H.III; Rose, J.B. Detection of viral pathogens by reverse transcriptase PCR and of microbial indicators by standard methods in the canals of the Florida Keys. Appl. Environ. Microbiol. 1999, 65, 4118-4125.

35. Grabow, W.O.K.; Taylor, M.B.; de Villiers, J.C. New methods for the detection of viruses: Call for review of drinking water quality guidelines. Water Sci. Technol. 2001, 43, 1-8.

36. Pina, S.; Buti, M.; Jardi, R.; Clemente-Casares, P.; Jofre, J.; Girones, R. Genetic analysis of hepatitis A virus strains recovered from the environment and from patients with acute hepatitis. J. Gen. Virol. 2001, 82, 2955-2963.

37. Castello, A.A.; Arguelles, M.H.; Rota, R.P.; Olthoff, A.; Jiang, B.; Glass, R.I.; Gentsch, J.R.; Glikmann, G. Molecular epidemiology of Group A rotavirus diarrhea among children in Buenos Aires, Argentina, from 1999 to 2003 and emergence of the infrequent genotype G12. J. Clin. Microbiol. 2006, 44, 2046-2050.

38. Gersberg, R.M.; Rose, M.A.; Robles-Sikisaka, R.; Dhar, A.K. Quantitative detection of hepatitis A virus and enteroviruses near the United States-Mexico border and correlation with levels of fecal indicator bacteria. Appl. Environ. Microbiol. 2006, 72, 7438-7444.

39. Meleg, E.; Banyai, K.; martella, V.; Jiang, B.; Kocsis, B.; Kisfali, P.; Melegh, B.; Szucs, G. Detection and quantification of group $\mathrm{C}$ rotaviruses in communal sewage. Appl. Environ. Microbiol. 2008, 74, 3394-3399.

40. Cunliffe, N.A.; Ngwira, B.M.; Dove, W.; Nakagomi, O.; Nakagomi, T.; Perez, A.; Hart, C.A.; Kazembe, P.N.; Mwansambo, C.V. Serotype G12 rotaviruses, Lilongwe, Malawi. Emerg. Infect. Dis. 2009, 15, 87-90

41. Kiulia, N.M.; Netshikweta, R.N.A.; van Zyl, W.B.; Kiraithe, M.M.; Nyachieo, A.; Mwenda, J.M.; Taylor, M.B. The detection of enteric viruses in selected urban and rural river water and sewage in Kenya, with special reference to rotaviruses. J. Appl. Microbiol. 2010, 109, 818-828.

42. Grabow, W.O.K.; Taylor, M.B.; Wolfaardt, M. Research on Human Viruses in Diffuse Effluents and Related Water Environments; Water Research Commission: Pretoria, South Africa, 1996; pp. 1-25.

43. Vivier, J.C.; Clay, C.G.; Grabow, W.O. Detection and rapid differentiation of human enteroviruses in water sources by restriction enzyme analysis. Water Sci. Technol. 2001, 4, 209-212.

44. Pavlov, D.N. Poliovirus vaccine strains in sewage and river water in South Africa. Can. J. Microbiol. 2006, 52, 717-723. 
45. Nadan, S.; Walter, J.E.; Grabow, W.O.K.; Mitchell, D.K.; Taylor, M.B. Molecular characterization of astroviruses by reverse transcriptase PCR and sequence analysis: Comparison of clinical and environmental isolates from South Africa. Appl. Environ. Microbiol. 2003, 69, 747-753.

46. Genthe, B.; Idema, G.K.; Kfir, R.; Grabow, W.O.K. Detection of rotavirus in South African waters: A comparison of a cytoimmunolabelling technique with commercially available immunoassays. Water Sci. Technol. 1991, 24, 241-244.

47. van Zyl, W.B.; Williams, P.J.; Grabow, W.O.; Taylor, M.B. Application of a molecular method for the detection of group A rotaviruses in raw and treated water. Water Sci. Technol. 2004, 50, 223-228.

48. Pourcher, A.M.; Picard-Bonnaud, F.P.B.; Agnieszka, V.F.; Vasilica, S.; Gerard, M. Survival of faecal indicators and enteroviruses in soil after land-spreading of municipal sewage sludge. Appl. Soil Ecol. 2007, 35, 473-479.

49. Muscillo, M.; Pourshaban, M.; Iaconelli, M.; Fontana, S.; Di Grazia, A.; Manzara, S.; Fadda, G.; Santangelo, R.; La Rosa, G. Detection and quantification of human adenoviruses in surface waters by nested PCR, TaqMan real-time PCR and cell culture assays. Water Air Soil Pollut. 2008, 191, $1-11$.

50. Jurzik, L.; Hamza, I.A.; Puchert, W.; Überla, K.; Wilhelm, M. Chemical and microbiological parameters as possible indicators for human enteric viruses in surface water. Int. J. Hygi. Environ. Health 2010, 213, 210-216.

51. Dahling, D. Detection and enumeration of enteric viruses in cell culture. CRC Rev. Environ. Contamin. 1991, 21, 237-263.

52. Schvoerer, E.; Bonneta, F.; Duboisa, V.; Cazauxb, G.; Serceauc, R.; Fleurya, H.J.A.; Lafona, M.E. PCR detection of human enteric viruses in bathing areas, waste waters and human stools in southwestern France. Res. Microbiol. 2000, 151, 693-701.

53. Griffin, D.W.; Donalson, K.A.; Paul, J.H.; Rose, J.B. Pathogenic human viruses in coastal waters. Clin.Microbiol. Rev. 2003, 16, 129-143.

54. de Paula, V.S.; Diniz-Mendes, L.; Villar, L.M.; Luz, S.L.B.; Silva, L.A.; Jesus, M.S.; da Silva, M.N.V.S.; Gaspar, A.S. Hepatitis A in environmental water samples from the Amazon Basin. Water Res. 2007, 41, 1169-1176.

55. Rodríguez, R.A.; Pepper, I.L.; Gerba, C.P. Application of PCR-based methods to assess the infectivity of enteric viruses in environmental samples. Appl. Environ. Microbiol. 2009, 75, 297-307.

56. Costafreda, M.I.; Bosch, A.; Pinto, R.M. Development, evaluation, and standardization of a real-time TaqMan reverse transcription-PCR assay for quantification of hepatitis A virus in clinical and shellfish samples. Appl. Environ. Microbiol. 2006, 72, 3846-3855.

57. Gregory, J.B.; Litaker, R.W.; Noble, R.T. Rapid one-step quantitative reverse transcriptase PCR Assay with competitive internal positive control for detection of enteroviruses in environmental samples. Appl. Environ. Microbiol. 2006, 72, 3960-3967.

58. Haramoto, E.; Katayama, H.; Oguma, K.; Ohgaki, S. Recovery of viral genomes in water by virus concentration methods. J. Virol. Methods 2007, 142, 169-173.

59. Jothikumar, N.; Kang, G.; Hill, V.R. Broadly reactive TaqMan assay for real-time RT-PCR detection of rotavirus in clinical and environmental samples. J. Virol. Methods 2009, 155, 126-131. 
60. Zhang, M.; Zhao, H.; Yang, J.; Jiang, S.; Cai1, B. Detection and quantification of enteroviruses in coastal seawaters from Bohai Bay, Tianjin, China. J. Environ. Sci. 2010, 22, 150-154.

61. Hamza, I.A.; Jurzik, L.; Stang, A.; Sure, K.; Uberla, K.; Wilhelm, M. Detection of human viruses in rivers of a densly-populated area in Germany using a virus adsorption elution method optimized for PCR analyses. Water Res. 2009, 43, 2657-2668.

62. Bofill-Mas, S.; Calgua, B.; Clemente-Casares, P.; La Rosa, G.; Iaconelli, M.; Muscillo, M.; Rutjes, S.; de Roda Husman, A.M.; Grunert, A.; Graber, I.; Verani, M.; Carducci, A.; Calvo, M.; Wyn-Jones, P.; Girones, R. Quantification of human adenoviruses in European recreational waters. Food Environ. Virol. 2010, 2, 101-109.

63. Donia, D.; Bonanni, E.; Diaco, L.; Divizia, M. Statistical correlation between enterovirus genome copy numbers and infectious viral particles in wastewater samples. Lett. Appl. Microbiol. 2010, 50, 237-240.

64. Parshionikar, S.; Laseke, I.; Fout, G.S. Use of propidium monoazide in reverse transcriptase PCR to distinguish between infectious and noninfectious enteric viruses in water samples. Appl. Environ. Microbiol. 2010, 76, 4318-4326.

65. River Health Programme (RHP). State-of-Rivers Report: Buffalo River System; Department of Water Affairs and Forestry: Pretoria, South Africa, 2004; pp. 1-41.

66. American Public Health Association (APHA). Standard Methods for the Examination of Water and Wastewater, 20th ed.; APHA: Washington DC, USA, 1998.

67. Haramoto, E.; Katayama, H.; Oguma, K.; Ohgaki, S. Application of cation-coated filters method to detection of noroviruses, enteroviruses, adenoviruses and torque teno viruses in the Tamagawa River in Japan. Appl. Environ. Microbiol. 2005, 71, 2403-2411.

68. Department of Water Affairs (DWAF). 2012 Green Drop Progress Report; Department of Water Affairs: Pretoria, South Africa, 2012.

69. Arankalle, V.A.; Ramakrishnan, J. Simian hepatitis A virus derived from a captive rhesus monkey in India is similar to the strain isolated from wild African green monkeys in Kenya. J. Viral Hepati. 2009, 16, 214-218.

70. Amado, L.A.; Marchevsky, R.S.; de Paula, V.S.; Hooper, C.; Freire, M.D.S.; Gaspar, A.M.C.; Pinto, M.A. Experimental hepatitis A virus (HAV) infection in cynomolgus monkeys Macaca fascicularis: Evidence of active extrahepatic site of HAV replication. Int. J. Exp. Pathol. 2010, 91, 87-97.

71. Global Alert Response (GAR): Hepatitis A, 2012. World Health Organization (WHO). Available online: http://www.who.int/csr/disease/hepatitis/whocdscsredc2007/en/index3.html (accessed on 9 October 2012).

72. Lodder, W.J.; van den Berg, H.H.J.L.; Rutjes, S.A.; de Roda Husman, A.M. Presence of enteric viruses in source waters for drinking water production in the Netherlands. Appl. Environ Microbiol. 2010, 76, 5965-5971.

73. Steele, A.D.; Glass, R. Rotavirus in South Africa: From discovery to vaccine introduction. South Afri. J. Epidemiol.Infect. 2011, 26, 184-190.

74. Ehlers, M.M.; Grabow, W.O.K.; Pavlov, D.N. Detection of enteroviruses in untreated and treated drinking water supplies in South Africa. Water Res. 2005, 39, 2253-2258. 
75. Harvala, H.; McIntyre, C.L.; Imai, N.; Clasper, L.; Djoko, C.F.; Lebreton, M.; Vermeulen, M.; Saville, A.; Mutapi, F.; Tamoufe, U.; et al. High seroprevalence of enterovirus infections in apes and old world monkeys. Emerg. Infect. Dis. 2012, 18, 283-286.

76. Chen, C.H.; Hsu, B.M.; Wan, M.T. Detection of enteroviruses within brackish water from the Damshui River watershed, Taiwan. J. Environ. Engineer. 2008, 134, 486. doi: 10.1061/(ASCE) 0733-9372(2008)134:6(486).

77. Skraber, S.; Gassilloud, B.; Schwartzbrod, L.; Gantzer, C. Survival of infectious Poliovirus-1 in river water compared to the persistence of somatic coliphages, thermotolerant coliforms, and poliovirus-1 genome. Water Res. 2004, 38, 2927-2933.

(C) 2012 by the authors; licensee MDPI, Basel, Switzerland. This article is an open access article distributed under the terms and conditions of the Creative Commons Attribution license (http://creativecommons.org/licenses/by/3.0/). 